\title{
Does the Pecking Order Theory Apply to Chinese Publicly Traded Companies? Evidence from Manufacturing Sector
}

\author{
Yue Yuan \\ School of Economics and Management, Leshan Normal University, Leshan, China \\ Email:344856692@qq.com
}

How to cite this paper: Yuan, Y. (2018) Does the Pecking Order Theory Apply to Chinese Publicly Traded Companies? Evidence from Manufacturing Sector. Modern Economy, 9, 2233-2247.

https://doi.org/10.4236/me.2018.912138

Received: November 16, 2018

Accepted: December 22, 2018

Published: December 25, 2018

Copyright $\odot 2018$ by author and Scientific Research Publishing Inc. This work is licensed under the Creative Commons Attribution International License (CC BY 4.0).

http://creativecommons.org/licenses/by/4.0/

\section{(c) (i) Open Access}

\begin{abstract}
The pecking order theory is one of the most crucial theories in corporate finance field. Empirical test on this theory is very common in western countries while domestic empirical study is still relatively limited in China. The majority of previous studies mainly concentrate in the whole capital market. Over the last decade, manufacturing sector experienced incrementally rapid development in China. The manufacturing sector not only makes critical contributions to China's economy and society development, but also becomes key force in supporting the world economy. Thus, this article tests pecking order theory on Chinese publicly traded firms in manufacturing sector. Using a panel of 1212 observations during the period between 2013 and 2015, we draw the conclusion that there is no evidence to back up the pecking order theory. Further subsample analysis indicates that pecking order does not apply to Chinese manufacturing listed firms with both high float shares ratio and low float shares ratio.
\end{abstract}

\section{Keywords}

Chinese Manufacturing, Pecking Order Theory, Market

\section{Introduction}

For enterprises, the establishment, business operations and sustainable development all need support of a lot of capital. No matter what a huge difference exists in organization regardless of the asset size, operating conditions, and market share, enterprises desire to raise short-term funds to stabilize the business situation, and to raise long-term funds to seek future development. With the development of modern financial markets, the choices for financing channels are in- 
creasingly diverse, yet in general financing method still can be summarized in three main ways: the internal financing, debt financing and equity financing.

Western scholars have been studying enterprises' financing preference for a long time. The pecking order hypothesis proposed by Myers and Majluf [1] brings research of the modern corporate finance to a new height. Generally speaking, western scholars believe that the pecking order theory has high explanatory power for firms' financing behavior. Under normal circumstances, when companies face funding gap, they prefers internal funds, followed by debt financing, and finally equity financing. Internal financing and debt financing often accounted for most of the company's financing.

But in China, the application of pecking order theory has been challenged. During the period between 2000 and 2005, empirical studies conducted by Chinese scholars confirm that serious equity financing preference does exist in China's listed companies (Huang and Zhang) [2]. However, the Chinese capital market reached an important historic turning point in 2005 and 2007. In 2005, when the Chinese stock market continued to slump, the market focused on "split-share structure phenomenon". China Securities Regulatory Commission issued "Guidance on the split-share reform on listed companies", officially declaring that equity division reform will be fully expanded in Chinese listed companies. In 2007, the corporate bond market that has been neglected for long time in China ushered in its own development opportunities. In order to break a variety of restrictions of domestic bond market on Chinese companies, China Securities Regulatory Commission promulgated the "Company bonds experimental approach", marking that China's corporate bond market officially started.

Two events, "Split-share structure reform" and "the rise of the corporate bond market", are not the object of our article. This article concerns that, after the split-share reform, whether financing preference of China's listed companies varies or not?

In the past decade, manufacturing sector experienced incrementally rapid development in China. Both the overall scale and the comprehensive strength have been significantly increasing. Thus, it is of interest to study the financing behavior in Chinese manufacturing sector. Does pecking order theory apply to Chinese manufacturing listed firms?

Our study examines the financing preference of 404 Chinese listed firms with financing deficit in manufacturing industry. And then we test pecking order theory on subsamples classified by the percentage of floatable shares.

\section{Literature Review}

Myers and Majluf [1] propose the pecking order theory considering information asymmetry between management inside and potential investors outside to analyze the firm's financing choices. Managers on behalf of old shareholders know clearly about the current condition and the prospect of the firm while outside 
investors do not have access to the same information. In addition to the transaction costs arising from issuing new shares, firms have to accept the information costs due to asymmetric information. According to Myers, companies facing financing deficit think that internal funds is superior to external funds in presence of adverse selection. Financing by retained earnings (internal sources) offers less risk for firm because it is least affected by the costs of information and has less adverse selection problem. By contrast, both debt and equity are subject to adverse selection problems. For a potential investor, equity has much more risk than debt has. This is because equity has larger adverse selection risk premium. Therefore, investors outside will obviously pursue a higher rate of return on equity than on debt. Thus, for firms, they will fund all projects with internal funds (cash) as possible as they can. If additional extra funds are necessary, debt issue will be the first choice instead of equity. That is to say, for a firm in normal operations, equity is the last choice to fund projects and net debt issued should track the funding gap closely.

To test the applicability of the pecking order theory, a new model is introduced by Shyam-Sunder and Myers [3]. The logic behind this test is to see which type of the external financing fill firm's funding needs. In this regression, financing deficit is constructed from corporate accounts. The financing deficit is defined as the sum of dividends, capital expenditure, net working capital and operating cash flows. Shyam-Sunder and Myers assert that, except for companies at or near debt capacity, the pecking order implies that the financing gap should normally be traced perfectly by a change in debt issues. That is to say, if the pecking order theory applies to firms tested, the coefficient of financing deficit should equal one in the regression of net debt on financing deficit. Frank and Goyal [4] conduct an empirical test to see if the Shyam-Sunder and Myers conclusions are applicable for broader companies and if their conclusions apply to subsamples of firms which are always predicted to face severe information asymmetry phenomenon. Using a large sample of listed US firms between year 1971 and year 1998, Frank and Goyal find that the estimate of pecking order coefficient is much lower than 1 . That is to say, net shares issued match the funding gap more closely, whereas the net debt issues do not. Lemmon and Zender [5] argue that as Chirinko and Singha [6] said, if pecking order hypothesis holds, in the presence of debt capacity constraints, the relation between net debt and funding deficit should be concave. Thus, Lemmon and Zender [5] modify Shyam-Sunder and Myers model, adding squared funding deficit as an extra regress or in order to acquire the concave feature in the equation. With the increase in financing needs, the firm approaches the debt capacity constraint point closely. Once firms' debt capacity exceeds debt constraint point, firms will use equity financing and reduce debt financing at the same time. The square of financing deficit also more completely describes the nature of pecking order because this variable considers the differences in funding choices between large and small deficits. 


\section{Methodology}

According to Shyam-Sunder and Myers [3], the pecking order theory is to test:

$$
\Delta D_{i t}=\alpha+\beta D E F_{i t}+\varepsilon_{i t}
$$

where $\Delta D_{i t t}$ denotes change in debt issues by firm $i$ in year $t$. Since financial statements of Chinese firms do not have long-term debt, we define $\Delta D_{i t t}$ as the change of short-term loan, long-term loan plus payable bonds. $\varepsilon_{i t}$ is the errr term. $D E F_{i t}$ is the flow of fund deficit defined as follows:

$$
D E F_{t}=D I V_{t}+X_{t}+\Delta W_{t}-C_{t}
$$

where

$D I V_{t}$ : cash payments for dividends, profits and interests in year $t$.

$X_{t}$ : capital expenditure is defined as the cash for purchasing fixed assets minus net cash received from disposal of fixed assets.

$\Delta W_{t}$ : change in working capital, and working capital is the difference between current assets and current liabilities.

$C_{t}$ : cash flows generated by operating business after taxes in year $t$.

The current portion of long-term debt is also a component in financing deficit in original Shyam-Sunder and Myers [3] model. But empirical results in Frank and Goyal [4] indicate that the current portion of long-term debt should be excluded from financing deficit. And we follow the definition for financing deficit in Frank and Goyal's [4] approach.

In the case of ideal conditions, changes in corporate debt issues should usually track the financing deficit perfectly, thus, the pecking order estimate $\beta$ should equals 1 and constant $\alpha$ approaches 0 , statistically significantly. Shyam-Sunder and Myers [3] do not include debt capacity constraints faced by companies in their empirical model, but they believe that the presence of borrowing constraints would only slightly reduce the coefficient $\beta$, which does not affect the empirical results, and the borrowing constraints faced by mature and large companies are not serious.

The pecking order theory argues that financing behavior is affected by adverse selection costs to a large extent. Therefore, this theory should best apply to companies facing particularly serious adverse selection problems. Small-sized companies at growth stage are often regarded as companies with large information asymmetries.

Shyam-Sunder and Myers [3] model has been criticized by some scholars, and it is considered that the explanatory power is not strong. Then I follow Lemmon and Zender [5] approach, adopting their modified model to do the more precise test. The empirical specification behind this model is:

$$
\Delta D_{i t}=\alpha+\beta D E F_{i t}+\gamma D E F_{i t}^{2}+\varepsilon_{i t}
$$

In this regression, if pecking order theory holds, the estimate of the pecking order parameter $(\beta)$ and $\mathrm{R}^{2}$ of the regression should see an obvious increase. Besides, estimating Equation (2) should lead to a statistically significant negative estimate of squared deficit coefficient. 
It should be noticed that not every firm has annual financing needs. A part of DEF (financing deficit) in our sample is less than 0 , suggesting that the firm doesn't need extra financing in corresponding year. Instead, the firm generates cash surplus through operating activities. In order to improve the explanatory power, maintaining empirical conclusions unchanged, three treatment methods are used in data processing:

1) Reserve observations with negative DEF value. We refer to this as sample 1.

2) Follow Liu et al. [7] approach: substitute DEF with adjusted DEF (ADEF), making $\mathrm{ADEF}=\operatorname{Max}(\mathrm{DEF}, 0)$. This is referred to as sample 2.

3) Exclude observations with negative DEF value. Since our goal is to examine how the firms with financing needs choose funds, it's better for enhancing the accuracy of the empirical results by excluding observations which have DEF less than 0 . This is referred to as sample 3.

A balanced panel of cross-section observations from manufacturing listed companies between 2013 and 2015 is used in our study on pecking order. First of all, we do the unit root test on all variables to see whether they are stationary or not. If they are non-stationary, we cannot run the regression through OLS method directly. Otherwise, it will result in spurious regression. Unit root test on our variables indicate that all of them have no unit root. They are stationary so that we can use OLS directly. Then, for a panel data, in order to investigate the relation in dimensions from space and time aspect, the pooled OLS (ordinary least squares) regression is the simplest method. If the intercept is a constant in the cross-section observations, then OLS model gives us efficient and unbiased estimates for intercept $\alpha$ and the slope coefficient of $\beta$. By doing the redundant fixed effects test, we can know that whether significant individual effects exist in our sample. If our observations show no remarkable individual effects, we could pool them together and run the regression using the ordinary least squares method; if there is individual effects or time effects, Hausman test is needed to decide which model is most appropriate for estimating our regression, namely the fixed effects model or random effects model. In the process of running the regression, panel estimated generalized least squares (EGLS) approach is adopted. It gives the residuals of each observation different weights so as to overcome the heteroscedasticity problem. This estimation gives the error term of regression model homoscedasticity. And it also helps resolve the contemporaneous cross-equation error (residual) correlation problem.

\section{Data and Preliminary Analysis}

A balanced panel of 1212 observations in manufacturing sector between 2013 and 2015 is collected from Shanghai Stock Exchange and Shenzhen Stock Exchange ${ }^{1}$.

The pecking order theory hypothesizes that companies do not issue much shares after going public. In other words, equity issues should approach zero. If ${ }^{1}$ http://www.sse.com.cn/, http://www.szse.cn/. 
this is true, in empirical test, the number of financing deficit and of net debt issued must be the same in Equation (1). However, Table 1 shows that this supposition is not correct. Table 1 summarizes values of each variable in Equation (1). It can be seen that much more equity is issued during the empirical period than debt issues. Besides, the number of funding deficit faced by these listed firms declines to the bottom in 2014 before increasing to the original level in 2015. However, it's interesting that the number of equity issues arrives at the peak in 2014. These figures indicate that observations in our sample issue increasing shares when their funding deficit is declining. During the same period, the net debt issues decline over time, suggesting that these manufacturing firms pay back the debt they issued instead of issuing new debt. On the other hand, Table 2 presents summary statistics for variables in Equation (1) and Equation (2). We can see the quantitative features of study sample of manufacturing listed companies. The mean of financing gap in our sample is $3.10 \mathrm{E}+08$, which indicates that in general manufacturing firms have a serious shortage of funds. At present, capital expenditure $\left(X_{t}\right)$ accounts for the largest amount among deficit. And the amount of cash flow $\left(C_{t}\right)$ driven from operating activities reaches $8.00 \mathrm{E}+08$ on average, illustrating that the firms in our sample have strong profitability and thus have sufficient internal funds to cover the funding gap.

Table 3 lists the summary of correlation among all variables in Equation (1) and Equation (2). It can be found that deficit and net debt is positively correlated and the correlation coefficient is 0.26 approximately, which indicates that the portion of extra capital needs financed by debt issues is low. Net working capital has the highest positive correlation with financing deficit, suggesting that extra needs for net working capital is most possible to lead to financing deficit. Both the operating cash flow and dividend are negatively correlated with financing deficit. The absolute value of these correlation coefficients is almost lower than 0.5. Therefore, there is no serious multicollinearity in our two regressions.

\section{Empirical Results}

In terms of panel data, the pooled OLS is used when the explanatory variable is independent of the error term. The redundant fixed effects test illustrates that there is no individual effect in our sample so that pooled OLS model is adopted here. Table 4 shows that, in sample 1 (with observations having negative financing deficit), the pecking order coefficient is 0.11 (in column (1)), significantly at $1 \%$ significance level. This figure demonstrates that $11 \%$ of funding gap is filled by debt issues in our overall sample. The explanatory power of the regression in this sample is very low, with $\mathrm{R}^{2}$ being 0.09 approximately. After adjustment, making negative financing deficit zero, we get sample 2. As presented in column (2) of Table 3, $\beta$ estimate is 0.15 and $\mathrm{R}^{2}$ is 0.13 . This pecking order figure indicates that on average only $15 \%$ of debt is issued when firms need financing. In sample 3 , which we exclude year-firms with negative financing deficit, we observe that pecking order coefficient approaches 0.19 and $\mathrm{R}^{2}$ of the re 
Table 1. Values of variables.

\begin{tabular}{cccc}
\hline \multirow{2}{*}{ Year } & \multicolumn{2}{c}{ Average funds flow and financing as a fraction of total assets } \\
\cline { 2 - 4 } & 2013 & 2014 & 2015 \\
\hline number of firms & 1212 & 1212 & 1212 \\
Dividend & 0.0251 & 0.0248 & 0.0240 \\
Capital expenditure & 0.0425 & 0.0406 & 0.0344 \\
$\Delta$ Working capital & 0.0204 & 0.0116 & 0.0360 \\
Internal cash flow & 0.0373 & 0.0439 & 0.0431 \\
Financing deficit & 0.0506 & 0.0331 & 0.0501 \\
Net debt & 0.0039 & -0.0006 & -0.0057 \\
Net equity & 0.0490 & 0.0538 & 0.0446 \\
Net external financing & 0.0529 & 0.0532 & 0.0389 \\
\hline
\end{tabular}

Note: recourses from the author.

Table 2. Summary statistics.

\begin{tabular}{ccccccc}
\hline variables & mean & median & Std. Dev. & minimum & maximum & observations \\
\hline$X_{t}$ & $6.91 \mathrm{E}+08$ & $1.71 \mathrm{E}+08$ & $2.12 \mathrm{E}+09$ & $-1.52 \mathrm{E}+09$ & $2.48 \mathrm{E}+10$ & 1212 \\
$D i v_{t}$ & $4.02 \mathrm{E}+08$ & $1.31 \mathrm{E}+08$ & $1.17 \mathrm{E}+09$ & 48491.67 & $2.32 \mathrm{E}+08$ & 1212 \\
$\Delta W_{t}$ & 17042153 & 28425444 & $2.34 \mathrm{E}+09$ & $-2.48 \mathrm{E}+10$ & $3.43 \mathrm{E}+10$ & 1212 \\
$C_{t}$ & $8.00 \mathrm{E}+08$ & $1.88 \mathrm{E}+08$ & $2.86 \mathrm{E}+09$ & $-9.72 \mathrm{E}+09$ & $4.44 \mathrm{E}+10$ & 1212 \\
$D E F_{t}$ & $3.10 \mathrm{E}+08$ & 91106959 & $3.59 \mathrm{E}+09$ & $-3.54 \mathrm{E}+10$ & $4.90 \mathrm{E}+10$ & 1212 \\
$D E F_{t}^{2}$ & $7.88 \mathrm{E}+18$ & $1.28 \mathrm{E}+17$ & $8.20 \mathrm{E}+19$ & $1.06 \mathrm{E}+10$ & $2.40 \mathrm{E}+21$ & 1212 \\
$\Delta D_{t}$ & $1.14 \mathrm{E}+08$ & 3101925 & $1.75 \mathrm{E}+09$ & $-1.75 \mathrm{E}+10$ & $1.50 \mathrm{E}+10$ & 1212 \\
\hline
\end{tabular}

Note: $\mathrm{aE}+\mathrm{n}$ is the scientific notation, representing that $\mathrm{a} \times 10 \mathrm{n}$. Recourses from the author.

Table 3. Variable correlations.

\begin{tabular}{|c|c|c|c|c|c|c|c|}
\hline \multicolumn{8}{|c|}{ variable correlation coefficient } \\
\hline & $D E F_{t}$ & $D E F_{t}^{2}$ & $\Delta D_{t}$ & $\operatorname{Div}_{t}$ & $\Delta W_{t}$ & $C_{t}$ & $X_{t}$ \\
\hline$D E F_{t}$ & 1 ----- & & & & & & \\
\hline$D E F_{t}^{2}$ & $\begin{array}{c}0.347028^{* * *} \\
(0.0000)\end{array}$ & 1----- & & & & & \\
\hline$\Delta D_{\mathrm{i}}$ & $\begin{array}{c}0.258943^{* * *} \\
(0.0000)\end{array}$ & $\begin{array}{c}0.073180^{\star *} \\
(0.0108)\end{array}$ & 1----- & & & & \\
\hline $\operatorname{Div}_{t}$ & $\begin{array}{c}-0.082908^{* * *} \\
(0.0039)\end{array}$ & $\begin{array}{c}0.264070^{* * *} \\
(0.0000)\end{array}$ & $\begin{array}{c}0.101266^{* * *} \\
(0.0004)\end{array}$ & 1---- & & & \\
\hline$\Delta W_{t}$ & $\begin{array}{c}0.626276^{* * *} \\
(0.0000)\end{array}$ & $\begin{array}{c}0.382163^{* * *} \\
(0.0000)\end{array}$ & $\begin{array}{c}0.001528^{* * *} \\
(0.9576)\end{array}$ & $\begin{array}{c}-0.239616^{* * *} \\
\quad(0.0000)\end{array}$ & 1----- & & \\
\hline$C_{t}$ & $\begin{array}{c}-0.344287^{* * *} \\
(0.0000)\end{array}$ & $\begin{array}{c}0.346707^{* * *} \\
(0.0000)\end{array}$ & $\begin{array}{c}-0.050527^{*} \\
(0.0787)\end{array}$ & $\begin{array}{c}0.719605^{* * *} \\
(0.0000)\end{array}$ & $\begin{array}{c}-0.069993^{* *} \\
(0.0418)\end{array}$ & 1 ----- & \\
\hline$X_{t}$ & $\begin{array}{c}0.207763^{* * *} \\
(0.0000)\end{array}$ & $\begin{array}{c}0.358020^{* * *} \\
(0.0000)\end{array}$ & $\begin{array}{c}0.215305^{* * *} \\
(0.0000)\end{array}$ & $\begin{array}{c}0.57338^{* * *} \\
(0.0000)\end{array}$ & $\begin{array}{c}-0.23992^{* *} \\
(0.0000)\end{array}$ & $\begin{array}{c}0.576197^{* * *} \\
(0.0000)\end{array}$ & 1---- \\
\hline
\end{tabular}

Note: ${ }^{*}$ demonstrates significance at the 0.1 level. ${ }^{* *}$ demonstrates significance at the 0.05 level. ${ }^{* * *}$ demonstrates significance at the 0.01 level. P-values are shown in parentheses. Recourses from the author. 
Table 4. Empirical result testing on Equation (1). Pecking Order Tests using panel EGLS (Cross-section weights), in manufacturing sector. Pooled OLS model is used when estimating. The tested period is 2013-2015. Columns (1)-(3) present the individual results for Equation (1) for sample 1, 2 and 3 respectively. The results contain an intercept figure, but not listed. P-values are presented in brackets. $\mathrm{N}$ is the number of observation.

\begin{tabular}{cccc}
\hline \multicolumn{4}{c}{$\Delta D_{i t}=\alpha+\beta D E F_{i t}+\epsilon_{i t}$} \\
\hline & sample 1 (1) & sample 2 (2) & sample 3 (3) \\
\hline$\beta$ & $0.109376^{* * *}$ & $0.145617^{* * *}$ & $0.189042^{* * *}$ \\
$\mathrm{~N}$ & $(0.0000)$ & $(0.0000)$ & $(0.0000)$ \\
$\mathrm{R}^{2}$ & 1212 & 1212 & 1212 \\
F-test & 0.087667 & 0.132549 & 0.321912 \\
\hline
\end{tabular}

Note: ${ }^{*}$ demonstrates significance at the 0.1 level. ${ }^{* *}$ demonstrates significance at the 0.05 level. ${ }^{* *}$ demonstrates significance at the 0.01 level. P-values are shown in parentheses. Recourses from the author.

gression increases to 0.32 , indicating that $19 \%$ of financing deficit is funded by debt financing. It is obvious that the regression has stronger explanatory power after excluding observations with negative financing deficit since our aim is to examine firms financing choices when extra funds are needed. All pecking order coefficients estimated from Equation (1) in three different samples are much smaller than 1, not consistent with the expectation behind Equation (1). Pecking order theory accepts some stocks issues, to a broad extent, so an estimate of pecking order coefficient being a little lower than 1 is acceptable. But this is still not supported in our sample due to the extremely low $\beta$ estimate and $\mathrm{R}^{2}$ (Table 5).

\subsection{Disaggregating the Data}

In order to test the pecking order theory on our manufacturing listed companies more particularly, we break down the data into three subgroups according to the free float methodology. Due to the fact that firms in our sample have relatively high free float ratio, we break down the overall sample into group 1 (float of shares no larger than $60 \%$ ), group 2 (float of shares between $60 \%-80 \%$ ), and group 3 (float of shares between $80 \%-100 \%$ ). We do both the redundant fixed effects test and Hausman test to choose the most appropriate regression model. And as mentioned above, panel EGLS is used in our regression. In terms of processing data, we follow the previous methods to treat the observations with negative financing deficit.

\subsection{Empirical Results on Group 1 (Firms with Floatable Shares below $60 \%$ )}

Analyzing our data, a panel of 99 companies that have float of shares below $60 \%$ are obtained. We do not exclude observations that have negative financing deficit when Estimating Equation (1) and Equation (2) on group 1, because the 
Table 5. Empirical result testing on Equation (2). Pecking Order Tests using panel EGLS (Cross-section weights), in manufacturing sector. Pooled OLS model is used when estimating. The tested period is 2013-2015. Columns (1)-(3) present the individual results for Equation (2) for sample 1, 2 and 3 respectively. The results contain an intercept figure, but not listed. P-values are presented in brackets. $\mathrm{N}$ is the number of observation.

\begin{tabular}{|c|c|c|c|}
\hline \multicolumn{4}{|c|}{$\Delta D_{i t}=\alpha+\beta D E F_{i t}+\gamma D E F_{i t}^{2}+\varepsilon_{i t}$} \\
\hline & sample $1(1)$ & sample $2(2)$ & sample $3(3)$ \\
\hline$\beta$ & $\begin{array}{c}0.106247^{* * *} \\
(0.0000)\end{array}$ & $\begin{array}{c}0.245484^{* * *} \\
(0.0000)\end{array}$ & $\begin{array}{c}0.311585^{\star * *} \\
(0.0000)\end{array}$ \\
\hline$\gamma$ & $\begin{array}{c}1.55 \mathrm{E}-12 \\
(0.2817)\end{array}$ & $\begin{array}{c}-1.19 \mathrm{E}-12^{*} \\
(0.7089)\end{array}$ & $\begin{array}{c}-4.22 \mathrm{E}-12^{*} \\
(0.0938)\end{array}$ \\
\hline $\mathrm{N}$ & 1212 & 1212 & 1212 \\
\hline $\mathrm{R}^{2}$ & 0.085075 & 0.234589 & 0.695547 \\
\hline F-test & $28.03525^{\star * *}$ & $92.40618^{\star * *}$ & $434.0704^{\star * * *}$ \\
\hline
\end{tabular}

Note: ${ }^{*}$ demonstrates significance at the 0.1 level. ${ }^{* *}$ demonstrates significance at the 0.05 level. ${ }^{* *}$ demonstrates significance at the 0.01 level. $\mathrm{aE}-\mathrm{n}$ is the scientific notation, representing that $\mathrm{a} \times 10^{-\mathrm{n}}$. Recourses from the author.

number of observations available in individual group is not very large. The redundant fixed effects test indicates that pooled OLS should be used on group 1. As seen in Table 6, the pecking order coefficient in column (1) is significant, arriving at 0.11 approximately. It can be interpreted that $11 \%$ of the funding gap is financed by debt issues. And the figure for sample 2, in which we substitute DEF with adjusted DEF (ADEF), making $\mathrm{ADEF}=\operatorname{Max}(\mathrm{DEF}, 0)$, is around 0.15. Thus, based on the prediction of Shyam-Sunder and Myers (1999) model, we conclude that Chinese manufacturing listed firms with float of shares between $0 \%-60 \%$ do not follow the pecking order hierarchy when they face funding needs. However, $\mathrm{R}^{2}$ of both samples is very low, which might is resulted from the small sample sizes. So we need to estimate Equation (2) to see more precise results and then make the conclusion.

Then we follow the Lemmon and Zender (2010) model to do more precise test on group 1. First of all, redundant fixed effects test suggests pooled OLS model. As column (1) of Table 7 shown, the estimate of $\beta$ coefficient is 0.10 , significantly, indicating that only $10 \%$ of financing gap is covered by debt issuing. The estimate of $\gamma$ parameteris negative $(-9.75 \mathrm{E}-12)$, which is also significant. This estimate suggests that when deficits exceed companies' debt capacity constraint companies turn to issuing a large number of equity to fill the financing gap. And the $\mathrm{R}^{2}$ increases from 0.10 to 0.54 . These features are still unable to prove the pecking order since the coefficient of financing deficit is still much smaller than 1. As for sample 2, column (2) of Table 7 presents that the $\beta$ coefficient sees an obvious increase from 0.05 to 0.23 , significantly at $1 \%$ significance level. This indicates that the financing gap is more possible to be financed by debt since filling the funding gap using debt is impossible to break companies' debt capacity constraints. Meanwhile, the estimate of $\mathrm{DEF}^{2}$ variable stays at $-7.94 \mathrm{E}-11$, 
Table 6. Empirical result on group 1 under Equation (1). Pecking Order Tests using panel EGLS (Cross-section weights), group 1 (float of shares no larger than 60\%). Pooled OLS model is used when estimating. The tested period is 2013-2015. Columns (1)-(2) present the individual results for Equation (1) for sample 1 and sample 2 respectively. The results contain an intercept figure, but not listed. P-values are presented in brackets. $\mathrm{N}$ is the number of observation.

\begin{tabular}{ccc}
\hline \multicolumn{3}{c}{$\Delta D_{i t}=\alpha+\beta D E F_{i t}+\varepsilon_{i t}$} \\
\hline$\beta$ & sample 1 (1) & sample 2 (2) \\
\hline $\mathrm{N}$ & $0.114128^{* * * *}$ & $0.149526^{* *}$ \\
$\mathrm{R}^{2}$ & $(0.0070)$ & $(0.0123)$ \\
F-test & 99 & 99 \\
\hline
\end{tabular}

Note: ${ }^{\star}$ demonstrates significance at the 0.1 level. ${ }^{* \star}$ demonstrates significance at the 0.05 level. ${ }^{* *}$ demonstrates significance at the 0.01 level. Recourses from the author.

Table 7. Empirical result on group 1 under Equation (2). Pecking Order Tests using panel EGLS (Cross-section weights), group 1 (float of shares no larger than $60 \%$ ). Pooled OLS model is used when estimating. The tested period is 2013-2015. Columns (1)-(2) present the individual results for Equation (2) for sample 1 and sample 2 respectively. The results contain an intercept figure, but not listed. P-values are presented in brackets. $\mathrm{N}$ is the number of observation.

\begin{tabular}{ccc}
\hline \multicolumn{3}{c}{$\Delta D_{i t}=\alpha+\beta D E F_{i t}+\gamma D E F_{i t}^{2}+\varepsilon_{i t}$} \\
\hline$\beta$ & sample 1 (1) & sample 2 (2) \\
\hline$\gamma$ & $0.101091^{* * *}$ & $0.226921^{* * *}$ \\
$\mathrm{~N}$ & $(0.0000)$ & $-7.9003)$ \\
$\mathrm{R}^{2}$ & $-9.75 \mathrm{E}-12^{\star * *}$ & $(0.0007)$ \\
F-test & $(0.0001)$ & 99 \\
& 99 & 0.37053 \\
\hline
\end{tabular}

Note: ${ }^{\star}$ demonstrates significance at the 0.1 level. ${ }^{* \star}$ demonstrates significance at the 0.05 level. ${ }^{* *}$ demonstrates significance at the 0.01 level. $\mathrm{aE}-\mathrm{n}$ is the scientific notation, representing that $\mathrm{a} \times 10^{-\mathrm{n}}$. Recourses from the author.

suggesting that firms turn to equity issues when the deficits exceeds debt capacity constraint point. And the $\mathrm{R}^{2}$ of this regression is 0.37 . After running regression on Equation (1) and Equation (2) and analyzing the estimates, it can be concluded that, in manufacturing sector, Chinese listed firms with circulation stocks lower than $60 \%$ do not follow pecking order when internal funds are exhausted. And this finding is consistent with the condition of firms that have relatively less tradable shares. At the beginning, the establishment of china's stock market aims to help state-owned enterprises raise funds. Thus when firms go public, the corporate stocks are artificially divided into floatable stocks and non-floatable stocks, in which non-floatable stocks occupy the absolutely domi- 
nant position. Non-tradable stocks are often issued at par, while the outstanding shares are issued at premium. Thus, the holding costs of non-tradable shareholders are much lower than the cost of shareholders who hold outstanding shares. In this case, refinancing will lead non-tradable shares to obtain equity appreciation undoubtedly. Therefore, the board controlled by non-tradable shareholders will not easily decide to give up equity financing when the firm needs extra financing. The absolute control by major shareholders causes the minority of shareholders unable to contend with the resolution of the board. These facts might give an explanation to our empirical results on group 1.

\subsection{Empirical Results on Group 2 (Firms with Floatable Shares between $60 \%$ - $80 \%$ )}

Findings for firms that have $60 \%-80 \%$ tradable shares show that pecking order theory does not hold in past three years. Redundant fixed effects test and Hausman test demonstrate that fixed effects model should be used here. It can be seen that the estimate of $\beta$ coefficient is -0.15 (Column (1) in Table 8), suggesting that when internal funds are exhausted firms choose to issue equity to finance capital gap and pay back about $15 \%$ debt that they issued in the past. Substituting DEF with adjusted DEF (making $\mathrm{ADEF}=\operatorname{Max}(\mathrm{DEF}, 0)$ ), we find that the figure for $\beta$ parameter is -0.17 , significantly at $1 \%$ significance level. Both samples have a moderately high $\mathrm{R}^{2}$. Obviously, these results show that manufacturing firms with $60 \%-80 \%$ outstanding stocks prefer equity financing instead of debt financing when there is funding deficit. Therefore, in this case, pecking order theory is not applicable to firms in group 2.

And the results obtained from estimating Equation (2) is consistent with it. The significantly negative slope coefficients in column (1) and (2) of Table 9 indicate that these firms choose equity issuing once internal funds are not enough to fund deficit. Although the estimates of squared financing deficit are both negative, they are not significant. Both samples have a moderately high $\mathrm{R}^{2}$. These firms have floatable shares between $60 \%-80 \%$, yet there is close interest nepotism between the big shareholders and controlling shareholders in most Chinese listed companies, including the manufacturing sector. These minority big shareholders might be the co-founder of the company when it was founded or equity investors introduced by controlling shareholders in order to meet listing requirements. Apart from this, big shareholders might be the family group of controlling shareholders. The presence of these minority big shareholders cannot effectively supervise the controlling shareholders, but will intensify the control by the controlling shareholders.

\subsection{Empirical Results on Group 3 (Firms with Floatable Shares between $80 \%$ - $100 \%$ )}

Results for firms with floatable shares between $80 \%-100 \%$ indicate that pecking order theory is not applicable for these firms. Based on redundant fixed effects 
Table 8. Empirical result on group 2 under Equation (1). Pecking Order Tests using panel EGLS (Cross-section weights), group 2 (float of shares between $60 \%-80 \%$ ). Fixed effects model is used when estimating. The tested period is 2013-2015. Columns (1)-(2) present the individual results for Equation (1) for sample 1 and sample 2 respectively. The results contain an intercept figure, but not listed. P-values are presented in brackets. $\mathrm{N}$ is the number of observation.

\begin{tabular}{ccc}
\hline \multicolumn{3}{c}{$\Delta D_{i t}=\alpha+\beta D E F_{i t}+\varepsilon_{i t}$} \\
\hline$\beta$ & sample 1 (1) & sample 2 (2) \\
\hline $\mathrm{N}$ & $-0.150282^{* * *}$ & $-0.174906^{* * *}$ \\
$\mathrm{R}^{2}$ & $(0.0000)$ & $(0.0000)$ \\
F-test & 153 & 0.719182 \\
\hline
\end{tabular}

Note: ${ }^{\star}$ demonstrates significance at the 0.1 level. ${ }^{* \star}$ demonstrates significance at the 0.05 level. ${ }^{* *}$ demonstrates significance at the 0.01 level. Recourses from the author.

Table 9. Empirical result on group 2 under Equation (2). Pecking Order Tests using panel EGLS (Cross-section weights), group 2 (float of shares between $60 \%-80 \%$ ). Fixed effects model is used when estimating. The tested period is 2013-2015. Columns (1)-(2) present the individual results for Equation (2) for sample 1 and sample 2 respectively. The results contain an intercept figure, but not listed. P-values are presented in brackets. $\mathrm{N}$ is the number of observation.

\begin{tabular}{ccc}
\hline \multicolumn{3}{c}{$\Delta D_{i t}=\alpha+\beta D E F_{i t}+\gamma D E F_{i t}^{2}+\varepsilon_{i t}$} \\
\hline$\beta$ & sample 1 (1) & sample 2 (2) \\
\hline$\gamma$ & $-0.125220^{* * * *}$ & $-0.182271^{* * *}$ \\
$\mathrm{~N}$ & $(0.0014)$ & $(0.0000)$ \\
$\mathrm{R}^{2}$ & $-1.82 \mathrm{E}-12$ & $-4.19 \mathrm{E}-13$ \\
F-test $^{*}$ & $(0.4748)$ & $(0.8751)$ \\
& 153 & 0.743556 \\
\end{tabular}

Note: ${ }^{*}$ demonstrates significance at the 0.1 level. ${ }^{* *}$ demonstrates significance at the 0.05 level. ${ }^{* *}$ demonstrates significance at the 0.01 level. $\mathrm{aE}-\mathrm{n}$ is the scientific notation, representing that $\mathrm{a} \times 10^{-\mathrm{n}}$. Recourses from the author.

test, pooled OLS model is appropriate when estimating both Equation (1) and Equation (2). According to the column (1) of Table 10 and Table 11, it can be observed that the estimate of pecking order coefficient increases from 0.22 to 0.24 . This demonstrates that financing gap is more possible to be financed by debt since filling the funding gap using debt is impossible to break companies' debt capacity constraints. And $24 \%$ of financing deficits are financed using debt issues after adding the square of financing deficit. It can be seen that the estimate of squared deficit is $9.54 \mathrm{E}-12$, which is not consistent with the prediction of Equation (2). Lemmon and Zender (2010) argue that there should be a concave function between the change of debt issues and financing deficit if pecking order theory is true empirically. Once the funding gap exceeds the debt capacity 
Table 10. Empirical result on group 3 under Equation (1). Pecking Order Tests using panel EGLS (Cross-section weights), group 3 (float of shares between $80 \%-100 \%$ ). Pooled OLS model is used when estimating. The tested period is 2013-2015. Columns (1)-(3) present the individual results for Equation (1) for sample 1, 2 and 3 respectively. The results contain an intercept figure, but not listed. P-values are presented in brackets. $\mathrm{N}$ is the number of observation.

\begin{tabular}{cccc}
\hline \multicolumn{4}{c}{$\Delta D_{i t}=\alpha+\beta D E F_{i t}+\varepsilon_{i t}$} \\
\hline & sample 1 & sample 2 & sample 3 \\
& $(1)$ & $(2)$ & $(3)$ \\
\hline$\beta$ & $0.219667^{* * *}$ & $0.313093^{* * *}$ & $0.353369^{* * *}$ \\
$\mathrm{~N}$ & $(0.0000)$ & $(0.0000)$ & $(0.0000)$ \\
$\mathrm{R}^{2}$ & 960 & 960 & 584 \\
F-test & 0.204101 & 0.31342 & 0.720028 \\
\hline
\end{tabular}

Note: ${ }^{*}$ demonstrates significance at the 0.1 level. ${ }^{* *}$ demonstrates significance at the 0.05 level. ${ }^{* *}$ demonstrates significance at the 0.01 level. Recourses from the author.

Table 11. Empirical result on group 3 under Equation (2). Pecking Order Tests using panel EGLS (Cross-section weights), group 3 (float of shares between $80 \%-100 \%$ ). Pooled OLS model is used when estimating. The tested period is 2013-2015. Columns (1)-(3) present the individual results for Equation (2) for sample 1, 2 and 3 respectively. The results contain an intercept figure, but not listed. P-values are presented in brackets. $\mathrm{N}$ is the number of observation.

\begin{tabular}{cccc}
\hline \multicolumn{4}{c}{$\Delta D_{i t}=\alpha+\beta D E F_{i t}+\gamma D E F_{i t}^{2}+\varepsilon_{i t}$} \\
\hline & sample 1 & sample 2 & sample 3 \\
& $(1)$ & $(2)$ & $(3)$ \\
\hline$\beta$ & $0.243513^{* * * *}$ & $0.214494^{* * *}$ & $0.286690^{* * *}$ \\
& $(0.0000)$ & $(0.0000)$ & $(0.0000)$ \\
$\gamma$ & $9.54 \mathrm{E}-12^{* * *}$ & $1.28 \mathrm{E}-11^{* * *}$ & $8.32 \mathrm{E}-11^{* * *}$ \\
$\mathrm{~N}$ & $(0.0000)$ & $(0.0000)$ & $(0.0000)$ \\
$\mathrm{R}^{2}$ & 960 & 960 & 584 \\
F-test & 0.372035 & 0.28792 & 0.84293 \\
\hline
\end{tabular}

Note: ${ }^{*}$ demonstrates significance at the 0.1 level. ${ }^{* *}$ demonstrates significance at the 0.05 level. ${ }^{* *}$ demonstrates significance at the 0.01 level. $\mathrm{aE}-\mathrm{n}$ is the scientific notation, representing that a $\times 10^{-\mathrm{n}}$. Recourses from the author.

constraint, firms will turn to equity issuing and reduce debt issues. The significantly positive $\mathrm{DEF}^{2}$ coefficient illustrates that firms with debt capacity constraints still choose issue debt when the funding deficit exceeds constraints point. For sample 2, $\mathrm{R}^{2}$ decreases from $32 \%$ to $29 \%$. And a decrease of slope deficit coefficient is also observed, which does not match the logic behind Lemmon and $\mathrm{Z}$ ender regression. Financing shortage should be more possible to be filled by debt issues so an increase in pecking order coefficient should be observed after adding squared deficit as extra regressor. The $\gamma$ estimate is significantly positive, indicating that these publicly traded companies still use debt financing when deficit exceeds debt constraint point. Excluding the time series observa- 
tions with financing deficit lower than zero, we obtain 584 observations left in sample 3. Column (3) of Table 10 shows that deficit is financed by around 35\% of debt issues and the goodness of fit approaches $72 \%$ approximately. But the results driven from estimating Equation (2) show no evidence of supporting the pecking order hypothesis. As seen in Table 11, we find that estimate for $\beta$ coefficient declines by about $7 \%$. And estimate for squared deficit is significantly positive, indicating that firms do not rely on equity financing when the deficit is large and exceeds debt capacity constraints. However, the explanatory power of this regression increases to $84 \%$.

\section{Conclusions}

Modern corporate finance theory originated from MM theorem [8] in the late 1950s. After that, research on corporate financing issues becomes the focus of modern corporate financing decisions. Under the given conditions for investment, the sources of corporate funds are mainly internal financing, equity financing and debt financing. Myers [9] made further research on this topic. He proposed the famous pecking order theory in the 1980s, based on the conclusion of classical corporate finance theory. The pecking financing theory considers incomplete information and adverse selection and argues that the financing hierarchy of firms is firstly internal funds, then debt financing and last equity financing. The basic logic behind the pecking order theory is very simple, namely, firms borrow funds because they need them. Because the high costs arising from asymmetric information on issuing equity, firms will choose debt financing as their incremental source of funding when internal sources such as cash are not enough to cover the deficit. The theory discusses corporate financing in terms of the information obtaining and gets universally verified in the western developed markets. Pecking order theory has attracted academic attention and become the mainstream of corporate finance theory. Because of the late start of China's security market development and huge difference of financing environment between developing market in China and western mature market, empirical test of pecking order theory on Chinese capital market shows the opposite conclusion; namely; Chinese listed companies prefer equity financing in terms of external financing.

Our article aims to examine the pecking order hypothesis on Chinese publicly traded companies in manufacturing sector during the period from 2013 to 2015. By using Shyam-Sunder and Myers [3] model and Lemmon and Zender [5] model, we find that pecking order theory does not hold in our sample. Further, we break down our sample based on the percentage of floatable shares of each firm. The results driven form each subsample show that neither firms with low float shares ratio nor firms with high float shares ratio issue debt primarily to cover financing deficit when internal funds are exhausted. It should be noticed that our article does not study whether these firms use internal sources to cover funding gap since the model we use is based on that firms use internal funds first. 


\section{Conflicts of Interest}

The author declares no conflicts of interest regarding the publication of this paper.

\section{References}

[1] Myers, S.C. and Majluf, N. (1984) Corporate Financing and Investment Decisions when Firms Have Information That Investors Do Not Have. Journal of Financial Economics, 13, 187-221. https://doi.org/10.1016/0304-405X(84)90023-0

[2] Huang, S.A. and Zhang, G. (2001) An Analysis of Chinese Listed Companies Equity Financing Preference. Economic Research Journal, 11, 12-20.

[3] Shyam-Sunder, L. and Myers, S.C. (1999) Testing Static Tradeoff against Pecking Order Models of Capital Structure. Journal of Financial Economics, 51, 219-244. https://doi.org/10.1016/S0304-405X(98)00051-8

[4] Frank, M.Z. and Goyal, V.K. (2003) Testing the Pecking Order Theory of Capital Structure. Journal of Financial Economics, 67, 217-248. https://doi.org/10.1016/S0304-405X(02)00252-0

[5] Lemmon, M.L. and Zender, J.F. (2010) Debt Capacity and Tests of Capital Structure Theories. Journal of Financial and Quantitative Analysis, 45, 1161-1187. https://doi.org/10.1017/S0022109010000499

[6] Chirinko, R.S. and Singha, A.R. (2000) Testing Static Tradeoff against Pecking Order Models of Capital Structure: A Critical Comment. Journal of Financial Economics, 58, 412-425. https://doi.org/10.1016/S0304-405X(00)00078-7

[7] Liu, X., et al. (2004) An Empirical Study on Chinese Listed Companies Financing Order. Accounting Research, 6, 66-72.

[8] Modigliani, F. and Miller, M.H. (1958) The Cost of Capital, Corporation Finance, and the Theory of Investments. American Economic Review, 48, 261-297.

[9] Myers, S.C. (1984) The Capital Structure Puzzle. Journal of Finance, 39, 575-592. https://doi.org/10.2307/2327916 